\title{
Uncertainty, Capital Investment, and Risk Management*
}

\author{
Hitesh Doshi ${ }^{\dagger} \quad$ Praveen Kumar ${ }^{\ddagger} \quad$ Vijay Yerramilli ${ }^{\S}$
}

March 2017

\begin{abstract}
We use forward-looking and exogenous measures of output price uncertainty to examine the effect of price uncertainty on firm-level capital investment, risk management, and debt issuance. The effects of uncertainty vary significantly by firm size. When faced with high price uncertainty, large firms increase their hedging intensity but do not lower capital investment or debt issuance. In contrast, small firms do not adjust their hedging intensity but significantly lower capital expenditure and debt issuance even after controlling for investment demand. Moreover, the negative effect of uncertainty on capital investment is significantly weaker for firms that hedge their output price risk. Our analysis highlights that, in the presence of financial frictions, high price uncertainty has significant dampening effects on capital investment of small firms by exacerbating their financial constraints, and that this negative effect is amplified by firm-level constraints on ability to hedge risk exposures.
\end{abstract}

Key Words: Uncertainty; capital investment; hedging; real options; financial frictions

JEL Codes: G31, G32, D92, D81

\footnotetext{
${ }^{*}$ An earlier version of the paper was titled "Uncertainty and Capital Investment: Real Options or Financial Frictions?"We thank two anonymous referees, the Associate Editor, Amit Seru (Department editor), Heitor Almeida, Murillo Campello, Jia Chen (discussant), Andras Danis (discussant), Hemang Desai, Andrew Ellul, Tom George, Radhakrishnan Gopalan, Gerard Hoberg, Rajesh Narayanan, Beau Page, Paul Povel, Amiyatosh Purnanandam, Latha Ramchand, Adriano Rampini, Rik Sen, Kumar Venkataraman, Malcolm Wardlaw (discussant), Toni Whited, Baozhong Yang (discussant), Alminas Zaldokas, and the seminar participants at Chinese University of Hong Kong, Hong Kong University of Science and Technology, Louisiana State University, Southern Methodist University, University of Houston, China International Conference in Finance (Shenzhen), Conference on Financial Economics and Accounting (Georgia State University), Lone Star Conference, and the Western Finance Association annual meetings (Monterey Bay) for their helpful comments and suggestions. We also thank Dimuthu Ratnadiwakara for valuable research assistance. All remaining errors are our responsibility.

${ }^{\dagger}$ C. T. Bauer College of Business, University of Houston; email: hdoshi@bauer.uh.edu

${ }^{\ddagger}$ C. T. Bauer College of Business, University of Houston; email: pkumar@uh.edu

${ }^{\S}$ C. T. Bauer College of Business, University of Houston; email: vyerramilli@bauer.uh.edu
} 


\section{Introduction}

Uncertainty is a major factor in the capital investment and financing decisions of firms, as seen repeatedly in surveys of financial managers (Graham and Harvey (2001)). Indeed, the effects of uncertainty on firm-level investment and financing policies have been of long-standing concern in finance and economics (Keynes (1936) and Myers (1977)). Consistent with the prominent role of uncertainty in corporate decisions, the literature shows that managers attempt to hedge or manage financial risk in a variety of ways (Campello et al. (2011)). Yet there is scarce empirical evidence regarding the causative effects of uncertainty on corporate policies and the potentially mitigating role of hedging. Although there is some evidence that uncertainty lowers capital investment, many important questions remain unanswered. Does risk management moderate the effect of uncertainty on capital investment, and how does risk management itself vary with uncertainty? Does uncertainty exacerbate financial frictions and affect firms' ability to raise new financing? Are the effects of uncertainty heterogeneous across firms, and if so what are the important drivers of this heterogeneity?

We address these questions by focusing on the U.S. upstream oil and gas (O\&G) sector, which offers us many advantages. First, we are able to obtain forward-looking and long-term measures of output price uncertainty for our sample firms derived from options on crude oil futures. Being derived from the market-clearing options prices over time, our uncertainty measures reflect the dynamically evolving and forward-looking price uncertainty assessments of the heterogeneous agents that trade in futures markets (Singleton (2014)). Importantly, most analysts agree that, unlike the national oil companies of the major oil producing countries and the large integrated firms with downstream and midstream refining operations (e.g., Chevron, Exxon-Mobil, and Royal Dutch Shell), independent firms in the US upstream O\&G sector act as price-takers in the world crude markets. ${ }^{1}$ Thus, our uncertainty measures can be treated as exogenous to the decisions of individual

\footnotetext{
${ }^{1}$ To reinforce this point, consider Apache Corporation, which is the largest firm in our sample. In 2012, Apache's annual crude oil production was 129 million bbl, a small fraction of the total U.S. production of around 2.4 billion $\mathrm{bbl}$, and minuscule in comparison to total world production of 27 billion bbl. It is clear from this example that even
} 
firms, which greatly aids identification. Second, because we have a homogeneous set of firms that operate in the same product market and are exposed to the same price uncertainty, we are able to create a measure of hedging intensity at the firm-quarter level that quantifies the fraction of risk exposure hedged by the firm. ${ }^{2}$ Finally, the $O \& G$ sector is particularly well-suited for this study because firms in this sector make large and irreversible capital investments in the face of considerable uncertainty (Arbogast and Kumar (2013)), which makes risk management central to their decision making.

We find that, on average, output price uncertainty has a statistically and economically significant negative effect on capital expenditure, but it has a significant positive effect on hedging intensity. Strikingly, these unconditional average effects of price uncertainty on capital investment and hedging mask substantial heterogeneity in the data. In particular, firms in the highest size quartile ("large" firms) increase their hedging intensity but do not lower their capital expenditure when faced with high price uncertainty. On the other hand, small firms do not vary their hedging intensity but lower their capital expenditure when faced with high price uncertainty. Moreover, hedging affects the sensitivity of capital expenditure to price uncertainty: After controlling for the endogeneity of the hedging decision, we find that the negative effect of price uncertainty on capital expenditure is significantly larger among firms that choose not to hedge during that quarter.

What is the channel through which hedging affects the investment-uncertainty relationship? The extant literature shows that debt market constraints have a negative effect on investment (Whited (1992), Almeida and Campello (2007), and Nini et al. (2012)) and hedging can alleviate debt market constraints (Campello et al. (2011)). However, the literature has only recently begun to explore whether high uncertainty exacerbates debt financing costs (see Section 2.2). If so, that can explain both the negative effect of price uncertainty on capital expenditure (independent of

the largest firm in our sample is unlikely to affect crude oil prices through its investment decisions.

${ }^{2}$ In most other industries, it would be infeasible to create such a measure of hedging intensity because it is not easy to measure risk exposures, and detailed hedging data at the firm level are not readily available. With the exception of a few papers that focus on commodity industries (e.g., see Haushalter (2000), Jin and Jorion (2006), and Kumar and Rabinovitch (2013)), most papers in the hedging literature measure hedging activity using either hedging dummies and/or the notional value of derivative contracts (e.g., see Purnanandam (2008), and Campello et al. (2011)). 
the real option channel), and why hedging will moderate this effect. We thus examine how price uncertainty affects net debt issuance, after controlling for firms' demand for debt. Consistent with the idea that price uncertainty exacerbates debt market frictions, we find that small firms significantly lower their debt issuance when faced with high price uncertainty (controlling for the demand for debt), whereas large firms do not. Moreover, the negative effect of price uncertainty on debt issuance is confined to firms that choose not to hedge during that quarter.

Past literature has highlighted that small firms and financially constrained firms are less likely to hedge their risk exposures (Haushalter (2000), Kumar and Rabinovitch (2013), and Rampini et al. (2014)), which may be due to economies of scale in hedging and firm-level collateral constraints (Rampini and Viswanathan (2010)). Our analysis shows that there is also a size effect in how firms vary their hedging with price uncertainty: large firms respond to high price uncertainty by increasing their hedging intensity, whereas small firms do not. This is likely due to institutional features of the O\&G sector and incompleteness in the exchange-traded derivatives market, which makes it onerous for small firms to vary their hedging intensity with price uncertainty.

An important contribution of our paper is thus to highlight that, in the presence of financial frictions, the negative effect of price uncertainty on capital investment may be amplified by firmlevel constraints on ability to hedge risk exposures. This is somewhat distinct from the classic real options argument that even unconstrained firms will optimally lower their capital investment when faced with high price uncertainty, because high uncertainty increases the value of the option to delay investment (McDonald and Siegel (1986) and Dixit and Pindyck (1994)). As per the classic real options argument, the effects of price uncertainty should be fairly homogeneous across technologically similar firms, and hedging should not have any effect on the investment-uncertainty relationship.

The average negative effect of uncertainty on firm-level capital investment is consistent with the industry-level evidence in Kellogg (2014), who uses data on oil drilling in Texas and a forward- 
looking measure of price uncertainty similar to ours. ${ }^{3}$ Despite this similarity, there are important differences between our paper and Kellogg (2014). To our knowledge, ours is the first study to empirically examine the joint effects of uncertainty on capital investment and hedging and how hedging may moderate the negative effect of price uncertainty on capital expenditure. We show that the negative relation between capital expenditure and price uncertainty is essentially a small firm phenomenon. On the other hand, large firms increase their hedging intensity when faced with high price uncertainty, but do not lower their capital expenditure. Moreover, our analysis is based on aggregate capital expenditure instead of the number of wells drilled, while controlling for important firm-level determinants of capital expenditure, such as $Q$.

\section{Theoretical and Institutional Background}

In this section, we build on the theoretical literature to generate empirical hypotheses regarding the effects of output price uncertainty on capital investment and risk management.

\subsection{Real Options, Uncertainty, and Capital Investment}

A large literature argues that the interaction of capital irreversibility and uncertainty generates a real option of delaying investment and awaiting the resolution of uncertainty (e.g., see McDonald and Siegel (1986) and Dixit and Pindyck (1994)). As the value of the option to wait increases with uncertainty, this literature predicts that higher uncertainty will, ceteris paribus, dampen capital investment. However, the effects of uncertainty on investment in the presence of capital adjustment costs are complex since the firm also faces increased expected expansion (or option exercise) costs by delaying investment. With competitive product markets (i.e., high price elasticity of demand), the expansion cost effect can dilute (if not neutralize) the real option motivation for delay (Caballero (1991)). In the upstream O\&G sector, there are non-trivial expansion costs, especially for larger

\footnotetext{
${ }^{3}$ A larger literature examines the relationship between corporate investment and other forms of uncertainty (i.e., other than output price uncertainty), such as economic policy uncertainty (Baker et al. (2016)), option-implied equity volatility (Stein and Stone (2012)), and stock market volatility or VIX (Bloom et al. (2007), and Bloom (2009)).
} 
and more technologically intensive projects, and firms are typically price-takers (as we argued in the introduction). Hence, the empirical resolution of the uncertainty-investment relation in our sample is of substantial interest.

It is also noteworthy that there is no role for hedging or risk management in canonical real options models, because they ignore financial frictions.

\subsection{Financial Frictions, Risk Management, and the Effects of Uncertainty}

The existing literature in finance shows that financial frictions affect the real investment decisions of firms (e.g., see Whited (1992), Almeida and Campello (2007), and Nini et al. (2012)). Financial frictions also generate incentives for firms to undertake risk management or hedging in order to mitigate costs of financial distress and to lower external financing costs (Smith and Stulz (1985) and Froot et al. (1993)). ${ }^{4}$

A recent literature shows conceptually and empirically that uncertainty aggravates financial constraints by raising debt costs which in turn reduces investment (Gilchrist et al. (2014) and Kumar and Yerramilli (2016)). ${ }^{5}$ That is, financially constrained firms may be forced to cut their capital investment because of their inability to raise sufficient debt capital. Therefore, we expect the negative effect of price uncertainty on capital investment to be stronger for more financially constrained firms, because they are more likely to be affected by debt market frictions. Moreover, if uncertainty aggravates financial frictions, then it is logical to expect that price uncertainty should have a positive effect on hedging intensity. However, to our knowledge, the literature has not examined empirically the joint effects of uncertainty on capital investment and hedging and how hedging may moderate the negative effect of price uncertainty on capital expenditure.

The effect of financial constraints on the uncertainty-investment relation, and the effect of un-

\footnotetext{
${ }^{4}$ Campello et al. (2011) and Kumar and Rabinovitch (2013) provide empirical evidence that hedging indeed mitigates financial constraints and lowers borrowing costs.

${ }^{5}$ Gilchrist et al. (2014) provide micro- and macro-level evidence that increases in uncertainty raise credit spreads, thereby dampening investment. In a model with endogenous costs of default, Kumar and Yerramilli (2016) show that increase in output price uncertainty raises firms' cost of debt financing.
} 
certainty on risk management are more complex when real options and financial frictions coexist. Kumar and Yerramilli (2016) predict that the negative effect of uncertainty on capital investment should be stronger for financially constrained firms, which will lower their capacity in a bid to minimize ex-post costs of financial distress. However, Boyle and Guthrie (2003) argue that the threat of future financing constraints may actually induce financially constrained firms to accelerate investment, thus weakening the real options effect. With regard to hedging and uncertainty, Adam et al. (2007) argue that firms with valuable real options may prefer to maintain exposure to price uncertainty and may actually hedge less as price uncertainty increases. Meanwhile, Rampini et al. (2014) emphasize trade-off between investment and risk management due to collateral constraints and predict that financially constrained firms should hedge less, but not necessarily reduce their investment. Given these ambiguous predictions, the empirical resolution of these issues is of substantial interest, in particular the impact of price uncertainty on the joint investment and hedging decisions of the firm.

\subsection{Fixed Costs and Hedging: The Role of Firm Size}

The literature highlights that firm size has a significant effect on corporate policies (Graham and Harvey (2001)). In particular, the positive association between hedging and firm size is well known in the risk management literature (Nance et al. (1993), Haushalter (2000), and Kumar and Rabinovitch (2013)). Although standard intuition may suggest that small firms should have greater incentives to hedge, the positive size-hedging relation is typically attributed to economies of scale due to the fixed costs of setting up risk management operations and employing specialist risk managers (Booth et al. (1984), Block and Gallagher (1986), and Dolde (1993)) and quantity discounts in derivatives markets (Nance et al. (1993)). Moreover, to the extent that small firms are likely to be more financially constrained, this evidence is also consistent with the argument in Rampini and Viswanathan (2010) and Rampini et al. (2014) that collateral constraints restrict hedging.

Institutional features of the O\&G industry and incompleteness in the exchange-traded deriva- 
tives markets may also affect how small and large firms differ in their hedging decisions, and how they vary hedging in response to price uncertainty. Historically, exchange-traded derivatives have had relatively short horizons, which makes it hard for upstream O\&G firms to hedge their risk exposures over long durations commensurate with the production horizons of their oil fields. ${ }^{6}$ Moreover, because wellhead prices depend on the sulfur content and other characteristics of crude oil, finding perfect hedges on the standardized, benchmark oil indices traded on exchanges is not generally feasible. Finally, because exchange traded O\&G futures are typically physically delivered, their standardized sizes imply that producers are not generally not able to precisely hedge their anticipated production.

Consequently, a substantial portion of hedging in the O\&G industry occurs through customized over-the-counter (OTC) derivative contracts intermediated through specialist brokers and banks (see Meyer (2012)). Because of their customization, OTC derivative contracts are typically bilateral and non-transferable, and settled without a third party, such as an exchange or central clearinghouse (McMahon (2010)). The absence of central clearing, along with the customization, generally makes OTC oil and gas contracts highly illiquid with a significant counterparty credit risk (Pirrong (2011)). In particular, because counterparty risk tends to rise as commodity prices fall, OTC hedge positions can not be easily 'scaled up' in such price environments. More generally, raising hedging intensity requires that a producer be able to find counterparties who are willing to accept the typically unique aspects of the producer's risk management needs.

Hence, varying hedging intensity with price uncertainty imposes significant search costs and requires specialized, full-time and experienced risk managers to execute (Dolde (1993)). Absorbing these fixed skilled labor costs is generally uneconomical for all but the larger O\&G firms. For example, in our sample of 126 firms (see Section 3), only 10 firms report having a board risk management committee. Moreover, and strikingly, $10 \%$ of small firms (i.e., those in the bottom

\footnotetext{
${ }^{6}$ For example, the trading horizons of the most liquid crude oil futures on the Chicago Mercantile Exchange (CME) and the Intercontinental Exchange (ICE), the two largest platforms for exchange traded derivatives in oil, do not exceed nine years (and markets are typically quite thin beyond five years). The effective hedging horizons are, therefore, often shorter than the production horizons of oil wells.
} 
three size quartiles) do not even have a separate CFO, and the chief executive officer (CEO) also acts as CFO (the corresponding number for firms in the lowest size quartile is $58 \%$ ). This evidence suggests that small firms are unlikely to be able to afford sophisticated risk management operations.

In light of this, we expect the positive effect of price uncertainty on hedging to be stronger for large firms, which are more likely to have sophisticated risk management operations. Consequently, because hedging lowers firms' effective exposure to price uncertainty and mitigates financial frictions, we expect the negative effect of price uncertainty on capital investment to be weaker for large firms.

\section{Sample Construction and Key Variables}

\subsection{Data Sources}

We collect daily data for all options and futures on crude oil between January 2, 1990 to March 31, 2013 from the Commodity Research Bureau. The futures and options on crude oil are among the most liquid across all commodities. The data contain information on a large cross-section of option contracts with varying maturities and strike prices, which allows for accurate computation of forward-looking measures of risk-neutral implied volatility. The average maturity of the option contracts in our sample increases substantially from 100 days in 1990 to 343 days in 2012. The maximum available maturity has also increased over the years from 369 days in 1990 to 1780 days in 2012. The average moneyness of option contracts (i.e., the ratio of strike to the underlying futures price) in our sample is $54 \%$ and the average maximum moneyness is $162 \%$. We use these data to compute model-free risk-neutral volatility.

We obtain firm financial information from the Compustat Quarterly files. As explained in the introduction, our analysis is focused on U.S. firms in the upstream oil \& gas sector. ${ }^{7}$ Compustat

\footnotetext{
${ }^{7}$ We classify a firm as US-based by applying the following criteria. First, we check for US incorporation by verifying that the firm's FIC variable in Compustat is set to "USA."Next, we verify that the main stock exchange on which the firm trades ( $E X C H G$ variable in Compustat) is a US exchange, which corresponds to the condition $11 \leq E X C H G \leq 18$. Finally, we check the firm's $S T A T E$ is within the United States.
} 
provides information on four different industry classification codes for each firm: National American Industry Classification System (NAICS), Standard Industry Classification $(S I C)$, S\&P Industry Sector Code $(S P C I N D C D)$, and the Global Industry Classification Sector Code (GSECTOR). We require all four codes to match before we classify a firm as belonging to the upstream oil \& gas sector. Specifically, we require that the firm's NAICS code must equal 211111 ("Crude Petroleum and Natural Gas Extraction"), its SIC code must equal 1311 ("Crude Petroleum and Natural Gas"), its SPCINDCD must equal 380 ("Oil and Gas (Exploration and Production)"), and its GSECTOR must equal 10 ("Energy"). Further, we require that our sample firms have least 8 quarters of financial information; our qualitative results are unchanged even if we include firms with fewer than 8 quarters of financial information. There are 197 firms that meet these requirements and their names are listed at the end of the Internet appendix.

We hand-collect information on hedging activities of our sample firms from their 10-Q filings with the SEC. We are able to collect this information for the post-1995 period, and for 126 firms in our sample. For this subsample, we have firm-level data on total volume of crude oil production and the quantity of crude oil that is hedged on a quarterly basis.

\subsection{Key Variables}

Our investment and hedging measures are defined at the quarterly level. We measure capital investment using the firms' capital expenditure (CAPEX) scaled by net property, plant and equipment (PP\&E) outstanding at the end of the previous fiscal quarter (we obtain qualitatively similar results if we scale with lagged assets instead of lagged net PP\&E). ${ }^{8}$ For the subsample of firms for which we have hedging data, we create a Hedging Intensity measure to denote the proportion of the firm's crude oil production during the quarter that the firm has hedged. We provide more details regarding the construction of these and all other variables in the Appendix.

\footnotetext{
${ }^{8}$ Firms in the O\&G sector do not report any research and development (R\&D) expenditures. Although they constantly explore for new oil and gas sources, drilling of exploratory wells is classified as capital expenditure and not as R\&D expenditure.
} 
Our key independent variable of interest is Price Uncertainty, which serves as forward-looking measure of oil price volatility at the one year horizon. We compute this as the option-implied volatility, using the method proposed by Bakshi et al. (2003), estimated from options on crude oil futures with maturity around one year. The detailed steps for the construction of this variable are outlined in Section (1) of the Internet appendix.

We use the price of crude oil futures (Futures Price) to proxy for investment demand as well as drilling and operating costs, and to differentiate the effect of price uncertainty from that of changes in the first moment. Firms' policies may also be affected by a host of macroeconomic factors, such as return on the market portfolio (S\&P 500 Return), return on oil futures (Oil Return), stock-market volatility (VIX), term spread (i.e., difference in yields between 10-year and 3-month US treasury bonds) and credit spread (i.e., difference in yields between BBB-rated and AAA-rated corporate bonds). Instead of including such a large number of highly correlated macroeconomic variables in the regression, we use principal component analysis (PCA) to extract the first and second principal component, denoted Macro 1st PC and Macro 2nd PC, which together account for $98 \%$ of the variation in these variables. ${ }^{9}$ We use Macro 1 st $P C$ and Macro $2 n d$ PC as time-varying proxies of financial frictions because they are likely to be positively related to firms' cost of capital. The first principal component loads heavily on term spread and the second principal component loads heavily on credit spread.

\section{Descriptive Statistics and Preliminary Results}

\subsection{Summary Statistics}

We assemble a panel dataset for 197 non-integrated exploration and production (E\&P) firms that are listed in the Internet Appendix. The non-integrated (E\&P) firms are not involved in downstream segments like refining and marketing and therefore, derive most of their cash flows from production

\footnotetext{
${ }^{9}$ We show that the results are similar if we include all the macroeconomic variables individually, instead of the macro principal components (see Panel A of Table IA-1 in the Internet Appendix).
} 
of crude oil and natural gas. Being non-integrated, these firms are not diversified through their physical or real assets and hence have incentives for risk management through financial contracts (see Kumar and Rabinovitch (2013)). The panel comprises of one observation for each firm-fiscal quarter ("firm-quarter") combination during 2Q1990-1Q2013. We match the oil price measures and other market measures with the quarterly panel data using the calendar dates corresponding to each observation in the data. For each firm-quarter, we extract the average oil volatility, average oil price, average VIX, quarterly return on 1-year crude oil future, and quarterly return on the S\&P500 index over the calendar quarter corresponding to the firm's fiscal quarter. We use contemporaneous market measures because these are available on a daily basis to corporate managers, and hence, may have a contemporaneous effect on firms' investment decisions. We verify that our qualitative results are the same even if we use lagged market measures.

We summarize our panel data set in Table $1 .{ }^{10}$ The size distribution of firms in the upstream O\&G sector is highly skewed, with the average firm being six times as large as the median firm in terms of the book value of total assets. Given the skewness of the size distribution, we use the natural logarithm of the book value of total assets (Size) as a proxy for firm size in all our empirical specifications. The summary statistics on Rated and Investment Grade indicate that $37.4 \%$ of the firms in our sample have a long-term credit rating, and that $35.8 \%$ of the firms have an investmentgrade rating (i.e., an S\&P rating of "BBB-" or better). Interestingly, 7.5\% of the firms in our sample do not have a separate Chief Financial Officer (CFO), because the Chief Executive Officer (CEO) also serves as the CFO in these firms. The skewness in the distribution of CFO compensation and CEO compensation mirrors the skewness in the distribution of size.

There is significant cross-sectional variation in capital expenditure across firm-quarters. While the median firm's quarterly CAPEX is $6.2 \%$ (as a fraction of its lagged PP\&E), the $25^{\text {th }}$ - and $75^{\text {th }}$-percentile values of $C A P E X$ are $3.4 \%$ and $10.5 \%$, respectively. We also verify there is significant within-firm variation in capital expenditure: in untabulated statistics, the mean (median)

\footnotetext{
${ }^{10}$ To mitigate the effect of outliers, we winsorize all firm financial ratios other than Leverage and Hedging Intensity at the $1 \%$ level in both tails. We winsorize Leverage and Hedging Intensity at the $1 \%$ level in the right tail only.
} 
value of within-firm standard deviation in $C A P E X$ is 0.074 (0.070), which is large compared to the mean (median) CAPEX.

The summary statistics on Hedging Intensity indicate that the average (median) firm hedges $29.6 \%(20.8 \%)$ of its oil production. There is substantial cross-sectional variation in hedging activity across firm-quarters, as indicated by the $25^{\text {th }}$ - and $75^{\text {th }}$-percentile values of 0 and 0.533 , respectively; that is, more than one-fourth of the firm-quarter observations in our sample do not involve any hedging, whereas at the other extreme, one-fourth of the firm-quarter observations feature firms that hedge more than half their output. However, unlike capital expenditure, there seems to be less within-firm variation in hedging intensity: in untabulated statistics, the mean (median) value of within-firm standard deviation in Hedging Intensity is 0.176 (0.198), which is small relative to the mean (median) Hedging Intensity of 0.296 (0.208).

The summary statistics on Price Uncertainty indicate that our main measure of output price uncertainty is not highly skewed, and does not suffer from the presence of outliers. We proxy for crude oil price (Futures Price) using the price of the crude oil futures contract with maturity closest to one year. During our sample period, Futures Price has varied between around $\$ 13$ per barrel and $\$ 146$ per barrel.

Next, we examine how the key firm characteristics vary by firm size. Accordingly, for each quarter, we classify firms into four quartiles by firm size, and define the dummy variable Large to identify firms that are in the highest size quartile; hence, Large $=0$ identifies small firms that are in the bottom three size quartiles. We present a univariate comparison of firm characteristics across small firms $($ Large $=0)$ and large firms $($ Large $=1)$ in Panel B; the last column lists the $p$-value of the difference in mean or median values. It is evident by comparing the mean and median values of total assets across the two columns that firms classified as large are an order of magnitude larger than firms classified as small. As expected, credit rating and executive compensation are highly positively correlated with size. Even then, it is striking that only $17.8 \%$ of small firms have an investment-grade rating, and $10 \%$ of these firms do not even have a separate CFO. The CFO 
compensation statistics indicate that only large firms are likely to be able to hire sophisticated CFOs and risk managers. Large firms also have significantly lower rates of capital expenditure and debt issuance, but have significantly higher hedging intensity compared to small firms. ${ }^{11}$

\subsection{Correlations Among Key Variables}

In Table 2, we report the pairwise correlations among the key variables in our panel. Panel A shows that Price Uncertainty is highly positively correlated with Futures Price and the two macroeconomic factors, Macro 1st PC and Macro 2nd PC. The high correlation between the oil factors and the macro factors is not surprising, and does not imply that oil price uncertainty is simply serving as a proxy for time-series variation in the macro variables. The causality could very well be the other way round, because oil is one of the most important commodities and a key input to most non-oil firms. Indeed, recent research in asset pricing shows that oil risk factors are important in explaining the movement of asset prices and economic fundamentals (e.g., see Chiang et al. (2015)). Nonetheless, these high correlations raise potential econometric concerns for our multivariate analysis, which we address in Section 5 below.

The pairwise correlations in Panel B suggest that O\&G firms lower their capital expenditure and increase hedging intensity when oil price uncertainty is high. On the other hand, they increase both capital expenditure and hedging intensity when the crude oil futures price is high. Of course, these are simple pair-wise correlations that do not control for other important determinants of investment and hedging decisions. We next proceed to the multivariate analysis where we are able to control for key determinants of investment and hedging activity.

\footnotetext{
${ }^{11}$ In unreported tests, we find similar differences between investment-grade firms and non-investment-grade firms (i.e., firms that are either unrated or have an S\&P rating worse than "BBB-"), which is not surprising given the evidence in this panel that large firms are also significantly more likely to have an investment-grade rating.
} 


\section{$5 \quad$ Main Empirical Results}

To examine how output price uncertainty affects firm-level capital investment and hedging activity, we estimate panel regressions of the form

$$
Y_{j, t}=\alpha+\beta * \text { Price Uncertainty }_{t}+\gamma X_{j, t-1}+\lambda X_{m, t}+\mu_{j}+\epsilon_{j, t}
$$

Here, $Y_{j, t}$ is either CAPEX or Hedging Intensity for firm ' $\mathrm{j}$ ' in fiscal quarter 't'. The main independent variable of interest is Price Uncertainty, which serves as a proxy for expected oil volatility one year into the future. The regression spans the time period 4Q1994 to 1Q2013 because Price Uncertainty is available beginning only in November 1994. We control for important firm characteristics $\left(X_{j, t-1}\right)$ and market and macroeconomic characteristics $\left(X_{m, t}\right)$ that can affect capital investment and hedging activity. ${ }^{12}$

As per the $Q$-theory of investment, a key determinant of investment is the firm's $Q$, defined as the ratio of the firm's market value to the replacement cost of its existing capital stock. Following standard practice in the literature, we use the book values of firms' assets as proxies for their replacement value, and compute $Q$ by dividing the sum of market value of equity and the book value of interest-bearing debt with the sum of the book values of equity and interest-bearing debt. We also control for the following additional firm characteristics that may affect capital investment and hedging activity: Size; Leverage, which is the ratio of long-term debt to assets; cash flow position using Cash Flow, which is the ratio of the sum of net income before extraordinary items and depreciation \& amortization to net property, plant \& equipment (PP\&E); Sales, which is defined as the ratio of sales to net PP\&E, and serves as a control for certain omitted aspects of the "true" Q or cash flows (Fazzari and Petersen (1993)); cash position using Cash, which is the ratio of cash and equivalents to total assets; Rated, which is a dummy variable that identifies if the firm

\footnotetext{
${ }^{12}$ To account for the joint determination of capital investment and hedging intensity decisions at the firm level, we also estimate a system of simultaneous equations approach to examine the simultaneous impact of Price Uncertainty on CAPEX and Hedging Intensity. We report these in Table IA-2 of the Internet Appendix, and show that our qualitative results are unchanged.
} 
has a long-term credit rating; and Dividends, which is a dummy variable that identifies if the firm pays any dividends to its common shareholders.

Capital investment and hedging activity in a cyclical industry like oil \& gas are also likely to be affected by the price of crude oil futures and other macroeconomic factors. Therefore, it is important to control the regression for Futures Price, Macro 1st PC and Macro 2nd PC. A potential econometric concern with the inclusion of these controls is that they have relatively high correlation with each other and with oil price uncertainty (see Panel A of Table 2). Therefore, we estimate the regressions with and without these macro controls to underline the robustness of our results. We also conduct several robustness tests which we describe below in Section 5.1, and report detailed results in the Internet Appendix.

The key identifying assumption underlying our analysis is that Price Uncertainty may be treated as exogenous conditional on the covariates. This is a reasonable assumption because U.S. firms in the upstream O\&G sector were marginal players in the global crude oil markets during our sample period and did not have the market power, either individually or collectively, to affect global crude oil prices. For our purposes, Price Uncertainty could not have been affected by the past or present policies of any firm in our sample. Moreover, after controlling for the price of crude oil futures and the two macroeconomic factors, we are confident that the residual in regression (1) is uncorrelated with Price Uncertainty. Nonetheless, we use the method proposed in Oster (2013) to estimate unbiased effects of Price Uncertainty.

\subsection{Capital Investment and Price Uncertainty}

To examine how output price uncertainty affects capital investment, we estimate the panel regression (1) with CAPEX as the dependent variable. The results of our estimation are reported in Table 3. The standard errors in all specifications are robust to heteroskedasticity and are clustered by quarter. We obtain qualitatively similar results if we cluster at the firm level.

Panel A shows the results of estimation on the entire sample of firms. In column (1), we include 
all firm level controls but omit Futures Price and the market/macro variables. We also include fiscal quarter dummies to control for any variation in capital expenditure across the four fiscal quarters in all estimations. The negative and significant coefficient on Price Uncertainty indicates that firms decrease their capital expenditure when price uncertainty is high. This effect is also economically significant: An increase in Price Uncertainty from its $25^{\text {th }}$-percentile to $75^{\text {th }}$-percentile level (an increase of 0.12 ) is associated with a decrease in CAPEX of $1.24 \%$, which represents a $14.4 \%$ (20.0\%) decrease in CAPEX relative to its mean (median) value of $8.6 \%(6.2 \%)$.

We introduce Futures Price as an additional control in column (2), and the two macro factors as additional controls in column (3). As expected, the coefficient on Futures Price is positive and significant, indicating that upstream O\&G firms undertake larger capital expenditure when the 1-year future price of crude oil is high. Notably, price uncertainty continues to have a statistically and economically significant negative effect on capital investment even after controlling for crude oil prices and time-varying proxies for financial frictions. Also, the magnitude of the coefficient on price uncertainty is similar between column (1) and column (3). Finally, in column (4) we include firm fixed effects to examine the relationship between within-firm variation in capital expenditure and price uncertainty, and find results very similar to the baseline regression in column (1). ${ }^{13}$

Overall, the results in Panel A of Table 3 indicate that, on average, firms lower their capital expenditure significantly — both in statistical and economic terms — when faced with high output price uncertainty.

In Panel B, we examine how the effect of price uncertainty on capital expenditure varies by firm size. Accordingly, we estimate the regression (1) separately for small firms (Large $=0$ ) and large firms $($ Large $=0)$, after controlling for all the determinants of capital expenditure from Panel A.

\footnotetext{
${ }^{13}$ Oster (2013) proposes a method to estimate the unbiased treatment effect by examining the changes in the $\beta$ coefficients and $R^{2}$ between an uncontrolled regression specification and a regression specification with a full set of observable control variables. In our setting, an uncontrolled regression with Price Uncertainty as the only regressor generates a $\beta$ of -0.088 with an $R^{2}$ of 0.0056 . Comparing these numbers with the regression in column (4) with the full set of controls and firm fixed effects, and applying the procedure described in Oster (2013) yields an unbiased coefficient estimate of -0.100 on Price Uncertainty. Instead, if we compare against the specification in column (3) without firm fixed effects, then we obtain an unbiased coefficient estimate of -0.091 on Price Uncertainty. These estimates provide comfort that the negative effect of Price Uncertainty on CAPEX is robust to omitted variable bias.
} 
This ensures that any differences in the response to Price Uncertainty across the two subgroups are driven only by differences in size, rather than by differences in investment opportunities or other firm characteristics. The empirical specification and control variables are the same as those in columns (1) through (3) of Panel A, but we suppress the coefficients on firm-level control variables to conserve space.

The striking finding from columns (1) and (2) is that there is no negative effect of price uncertainty on capital expenditure for large firms. ${ }^{14}$ As can be seen, the coefficient on Price Uncertainty is negative and significant only for the subgroup of small firms in column (1), and the difference in coefficients between columns (1) and (2) is highly significant. This differential effect of price uncertainty on capital expenditure for small versus large firms is robust to controlling for crude oil prices (columns (3) and (4)) and other macroeconomic factors (columns (5) and (6)).

Overall, the results in Panel B indicate that the negative relation between capital expenditure and price uncertainty is essentially a small firm phenomenon, and is absent among large firms. One possible explanation for this size effect is that large firms are able to increase their risk management in uncertain environments to protect their investment programs, whereas small firms are unable to do so. To test this conjecture, we examine the effect of price uncertainty on firm-level hedging policies in Section 5.2 below following a brief description of the robustness of our CAPEX results.

\section{Robustness Tests}

We conduct several additional robustness tests, which we report in Table IA-1 of the Internet Appendix to conserve space in the paper. In Panel A, we show that our results are similar if we include all the macroeconomic variables individually instead of the macro principal components, and that our results are robust to a purged residuals regression specification (see Clerides et al. (1998)). In Panel B, we show that our results are robust to a first-differences specification. Since

\footnotetext{
${ }^{14}$ In unreported tests, we find similar results when we estimate the regression separately for each of the four size quartiles. Specifically, we find that price uncertainty has a significant negative effect on capital expenditure for firms in each of the three bottom size quartiles, but has no effect for firms in the largest size quartile.
} 
the first-differences specification relies on "shocks" to the macroeconomic variables instead of their levels, high correlation among macro variables is no longer a concern. In Panel C, we obtain a time series of covariate-adjusted average capital expenditure and show that it has a negative relation with price uncertainty. In Panel D, we show that the negative effect of price uncertainty on capital expenditure holds for all levels of crude oil futures price. Finally, in Panel E, we show that the negative relationship between capital expenditure and price uncertainty is robust to a variety of alternative specifications, such as a fixed effects model with autocorrelated errors, a panel GMM specification, and a linear errors-in-variables specification.

\subsection{Hedging and Price Uncertainty}

To examine how output price uncertainty affects firm-level risk management policies, we estimate panel regression (1) with Hedging Intensity as the dependent variable. ${ }^{15}$ The results of our estimation are presented in Table 4.

In Panel A, we estimate the regression on our entire sample of firms. In column (1), we utilize the full set of firm-level control variables that we used in the CAPEX regression in Table 3. The positive and significant coefficient on Price Uncertainty indicates that, on average, firms hedge more when faced with higher output price uncertainty. The effect is also economically significant: the coefficient estimate in column (2) suggests that an increase in Price Uncertainty from its $25^{\text {th }}$ - to $75^{\text {th }}$ - percentile level (an increase of 0.12 ) is associated with a $4.7 \%$ increase in Hedging Intensity, which represents a $15.9 \%(22.6 \%)$ increase relative to its mean (median) value of $29.6 \%(20.8 \%)$.

The coefficients on firm-specific controls are consistent with the risk management literature. Size has a strong positive effect on hedging intensity. Ceteris paribus, firms use hedging intensity to reduce debt contracting costs, as seen by the significant positive coefficient for leverage and the negative coefficients for cash holdings, dividend payout, sales, and the presence of a credit rating.

The positive effect of price uncertainty on hedging intensity is robust to controlling for the

\footnotetext{
${ }^{15}$ As Hedging Intensity is clearly censored below at 0 , we verify that our results are robust to a Tobit specification.
} 
futures price of crude oil (column (2)) and other macroeconomic factors (column (3)). The results in column (2) also indicate that on average hedging intensity is significantly positively related to the futures price of crude oil, as hedging firms attempt to capture higher prices for their output.

In column (4), we introduce firm fixed effects in addition to the time-varying control variables. Note that the coefficient on Price Uncertainty becomes insignificant, whereas the coefficient on Futures Price continues to be positive and significant. Therefore, most of the within-firm variation in hedging intensity seems to be driven by futures price of oil, rather than by oil price uncertainty. We also note that, compared to capital expenditure, there is very little within-firm variation in hedging intensity in the first place. For instance, in unreported tests, we find that firm dummies (or fixed effects) alone can explain $55 \%$ of the $R^{2}$ in hedging intensity, whereas they explain only $12.5 \%$ of the variation in capital expenditure. Thus, hedging policies of firms seem to be very rigid, on average, compared to capital expenditure policies. Moreover, hedging seems to be much more stickier among small firms compared to large firms. For instance, the average change in hedging intensity relative to the previous quarter (i.e., $\Delta$ Hedging Intensity) is only $0.068 \%$ among small firms versus $0.78 \%$ among large firms.

In Panel B, we estimate the regression specifications from Panel A separately for small firms $($ Large $=0)$ and large firms $($ Large $=1)$ in order to understand how the effect of price uncertainty on hedging varies by firm size. The striking finding from Panel B is that the positive relationship between hedging intensity and price uncertainty is entirely driven by large firms. Recall that these are the same firms which do not lower their capital expenditure when faced with high price uncertainty (Panel B of Table 3). By contrast, small firms do not vary their hedging intensity significantly with price uncertainty, although, as we saw in Panel B of Table 3, the same group of firms lower their capital expenditure significantly when price uncertainty is high.

The invariance of hedging intensity to price uncertainty in small firms is of substantial interest. We note that this result is not driven by firms that do not hedge at all. Rather, as we argued in Section 2, this result may be explained by the institutional features of O\&G industry where most 
of the hedging occurs through customized and highly illiquid over-the-counter contracts, making it difficult for small firms to adjust their hedging intensity to price uncertainty.

\subsection{Effect of Hedging on the Investment-Uncertainty Relation}

Taken together, the results in Tables 3 and 4 suggest that hedging policies may affect how firms' capital investment responds to price uncertainty. Of course, both capital investment and hedging are endogenous and vary with price uncertainty, which makes it hard to characterize the effect of hedging on the sensitivity of capital investment to price uncertainty.

In this section, we employ a switching regression model with endogenous switching (Maddala (1983)) to examine how the sensitivity of capital expenditure to price uncertainty varies between firms that hedged at least some of their oil production during the quarter and those that did not, after adjusting for the endogeneity of the decision to hedge or not. We define the dummy variable Hedger to identify firms that hedged at least some of their oil production during the quarter; i.e., Hedger $=1$ identifies firms with Hedging Intensity $>0$, whereas Hedger $=0$ identifies firms with Hedging Intensity $=0$.

In the first stage of the model, we estimate a Probit regression with Hedger as the dependent variable, and use the serial correlation of taxable income $(\rho(T I))$ as a tax-based instrument for hedging (see Graham and Smith (1999)). For each firm in our sample, we estimate $\rho(T I)$ each year using the firm's entire history to that point. The argument is that, given the convexity of tax schedules, a firm's expected tax benefit from hedging is likely to be higher if its taxable income exhibits more negative serial correlation so that the firm is more likely to shift between profits and losses (see page 2256 of Graham and Smith (1999) for more details). ${ }^{16}$ By this logic, we expect

\footnotetext{
${ }^{16}$ Campello et al. (2011) use a similar approach with tax-based instruments to model the endogeneity of firms' hedging decisions. More generally, Graham and Smith (1999) define Tax Convexity to denote the tax benefits of hedging (specifically, the tax savings from a $5 \%$ reduction in volatility of taxable income) and relate it to firm-specific characteristics such as volatility and serial correlation of taxable income, net operating loss (NOL) carry-forwards, and investment tax credits. We choose to be agnostic about the actual shape of the Tax Convexity function in the upstream O\&G sector, because the coefficient estimates provided in Graham and Smith (1999) to compute Tax Convexity are based on regressions on a pooled sample of firm-year observations across all industries. Moreover, we are less confident that volatility of taxable income satisfies the exclusion restriction with respect to $C A P E X$. Also,
} 
a negative relationship between between $\rho(T I)$ and Hedger. At the same time, there is no reason to believe that $\rho(T I)$ affects the firm's current capital expenditure. Hence, we feel confident that $\rho(T I)$ satisfies the exclusion restriction.

In the second stage of the model, we estimate two outcome equations with CAPEX as the dependent variable, separately for firms that hedged $($ Hedger $=1)$ and for firms that did not hedge $($ Hedger $=0)$, after augmenting each equation using the Inverse Mills Ratio estimated from the first-stage Probit regression. The results of our estimation are presented in Table 5. We include the full set of control variables in both the first-stage selection equation and the second-stage outcome equations, but suppress these coefficients to conserve space.

We estimate the model on our entire sample in columns (1) and (3). The results show a marked distinction between the effects of price uncertainty on the capital investment of firms that hedged versus those that did not. Although the coefficient on Price Uncertainty is negative for both firms that hedged (column (2)) and those that did not (column (3)), the coefficient is much more economically and statistically significant among the subgroup of firms that chose not to hedge their exposure to price uncertainty. Moreover, the results of the $\chi^{2}$ test indicate that the difference in coefficients on Price Uncertainty between the two subgroups is statistically significant at the $10 \%$ level. The results of the first-stage Probit regression in column (1) indicate that $\rho(T I)$ is a strong instrument for hedging. The insignificant coefficients on Inverse Mills Ratio in columns (2) and (3) indicate that any omitted factors that affect the firms' hedging decision do not have a significant effect on capital expenditure.

Next, we estimate the switching regression separately for small firms (Large $=0$ ) and large firms (Large $=1$ ), but suppress the results of the first-stage Probit regressions in both cases to conserve space. We present the results of the second-stage regressions for small firms in columns (4) and (5), and for large firms in columns (6) and (7). As can be seen from columns (4) and

none of our sample firms report any investment tax credit on their balance sheets. Therefore, we use only $\rho(T I)$ as an instrument for hedging intensity, although our qualitative results are similar if we use all the explanatory variables in their paper as instruments. 
(5), among small firms, the negative effect of price uncertainty on capital expenditure seems to be larger among firms that chose not to hedge, although the difference between coefficients on Price Uncertainty narrowly misses statistical significance at the $10 \%$ level (the $p$-value of the difference is 0.11). On the other hand, we fail to detect any effect of hedging on the CAPEX-uncertainty relation among large firms. This may be because large firms face less severe financing constraints, regardless of whether they hedge or not. Alternatively, this result may reflect the limited statistical power of the test given that there are only 150 non-hedger firm-quarter observations among the subgroup of large firms.

\subsection{Price Uncertainty, Debt Market Frictions, and Hedging}

What is the channel through which hedging moderates the negative effect of price uncertainty on capital investment? One possibility is that price uncertainty exacerbates debt market frictions, which can be mitigated through hedging. Indeed, a large literature in finance shows that debt market constraints have a negative effect on capital investment (Whited (1992), Almeida and Campello (2007), and Nini et al. (2012)), and that hedging can alleviate debt market constraints (Campello et al. (2011)). However, the literature has not specifically examined if uncertainty exacerbates debt market frictions. If we can show that price uncertainty exacerbates debt market frictions, that can potentially explain why the effects of price uncertainty vary by firm size and hedging policies.

To this end, we examine the effect of price uncertainty on net debt issuance by firms, and how this effect varies with firm size and hedging activity. accordingly, we estimate regression (1) with $\Delta$ Net Debt as the dependent variable, which denotes the change in net debt (i.e., total debt minus cash and equivalents) from the previous quarter scaled by lagged assets. If output price uncertainty exacerbates debt market frictions, then we expect a negative relationship between debt issuance and price uncertainty, especially for small firms that are more likely to be affected by debt market frictions. 
The empirical challenge in this investigation is to differentiate between firms' supply of credit and demand for credit. That is, net debt issuance may be lower either because the firm is unable to raise debt (supply effect) or because the firm is undertaking less capital expenditure, and hence, does not need to raise debt (demand effect). Therefore, to partially control for the firm's demand for credit, we use Industry CAPEX, defined as the median value of $C A P E X$ across all sample firms over the same calendar quarter, as a proxy for investment opportunities in the sector. The results of our estimation are presented in Table 6 .

The results in Panel A indicate that firms lower their net debt issuance when price uncertainty is high, which is consistent with both the static "trade-off" model of capital structure (Kraus and Litzenberger (1973)) and dynamic structural models that consider investment and capital structure decisions (see Strebulaev and Whited (2011) for a survey). This result is also robust to controlling for the effect of oil futures price and macroeconomic factors (column (2)), and the inclusion of firm fixed effects (column (3)). The positive coefficient on Industry CAPEX indicates that firms issue more debt when investment demand is high. Examining debt issuance and cash accumulation separately, we find that price uncertainty has a significant negative effect on debt issuance (column (4)) but no significant positive effect on cash accumulation (column (5)).

In Panel B, we examine the effect of price uncertainty on debt issuance separately for small firms $($ Large $=0)$ and large firms (Large $=1)$. As can be seen, the negative effect of price uncertainty on net debt issuance is essentially a small firm phenomenon, and is absent among large firms. ${ }^{17}$

In Panel $\mathrm{C}$, we use the switching regression model with endogenous switching to examine how the effect of price uncertainty on net debt issuance varies between hedgers and non-hedgers. We first estimate this model on our entire sample of firms, the results of which are presented in columns (1) through (3). As can be seen, the negative effect of price uncertainty on $\Delta N e t$ debt is confined entirely to non-hedging firms, and the difference in coefficients on Price Uncertainty between columns (2)

\footnotetext{
${ }^{17}$ We also use a system of simultaneous equations approach to examine the joint effect of price uncertainty on $\Delta N e t$ Debt and Hedging Intensity. The results reported in Table IA-3 are consistent with the findings Panel A and B of Table 6 .
} 
and (3) is statistically significant at the $5 \%$ level.

Next, we estimate the switching regression model separately for small firms (Large $=0)$ and large firms $($ Large $=1)$, but suppress the results of the first-stage Probit regressions in both cases to conserve space. We present the results of the second-stage regressions for small firms in columns (4) and (5), and for large firms in columns (6) and (7). The results in columns (4) and (5) indicate that, among small firms, the negative effect of price uncertainty on $\Delta N e t$ debt is confined entirely to non-hedging firms, and the difference in coefficients on Price Uncertainty between the two columns is statistically significant at the $5 \%$ level. However, among large firms, price uncertainty has no effect on $\Delta$ Net debt, regardless of hedging.

Overall, the results in Table 6 suggest that, on average, firms face more severe debt market constraints when price uncertainty is high. However, the results in Panels B and C, respectively, show that large firms and firms that hedge do not face this problem.

\section{Conclusion}

In this paper, we use the U.S. upstream oil and gas sector as a laboratory to examine the causative effect of output price uncertainty on firm-level capital investment, risk management, and debt issuance. We use options on crude oil futures to derive a forward-looking and exogenous measure of price uncertainty. We find that the effects of uncertainty vary significantly by firm size. When faced with high price uncertainty, large firms increase their hedging intensity but do not lower capital expenditure or debt issuance. On the other hand, small firms do not adjust their hedging intensity but significantly lower capital expenditure and debt issuance even after controlling for investment demand. Moreover, the negative effect of uncertainty on capital investment is significantly weaker for firms that hedge their output price risk. Our analysis highlights that, in the presence of financial frictions, high price uncertainty has significant dampening effects on capital investment of small firms by exacerbating their financial constraints, and that this negative effect is amplified by firmlevel constraints on ability to hedge risk exposures. 


\section{References}

Adam, T., S. Dasgupta, and S. Titman (2007). Financial Constraints, Competition, and Hedging in Industry Equilibrium. Journal of Finance 62, 2445-2473.

Almeida, H. and M. Campello (2007). Financial Constraints, Asset Tangibility, and Corporate Investment. Review of Financial Studies 20, 1429-1460.

Arbogast, S. and P. Kumar (2013). Financing Large Projects. In B. Simkins and R. Simkins (Eds.), Energy Finance: Analysis and Valuation, Risk Management, and the Future of Energy . Wiley.

Baker, S. R., N. Bloom, and S. J. Davis (2016). Measuring Economic Policy Uncertainty. Quarterly Journal of Economics, Forthcoming.

Bakshi, G., N. Kapadia, and D. Madan (2003). Stock Return Characteristics, Skew Laws, and Differential Pricing of Individual Equity Options. Review of Financial Studies 10, 101-143.

Block, S. B. and T. J. Gallagher (1986). The Use of Interest Rate Futures and Options by Corporate Financial Managers. Financial Management 15, 73-78.

Bloom, N. (2009). The Impact of Uncertainty Shocks. Econometrica 77, 623-685.

Bloom, N., S. Bond, and J. van Reenen (2007). Uncertainty and Investment Dynamics. Review of Economic Studies 74, 391-415.

Booth, J. R., R. L. Smith, and R. W. Stolz (1984). The Use of Interest Rate Futures by Financial Institutions. Journal of Bank Research 15, 15-20.

Boyle, G. W. and G. A. Guthrie (2003). Investment, Uncertainty, and Liquidity. Journal of Finance 58, 2143-2166.

Caballero, R. J. (1991). On the Sign of the Investment-Uncertainty Relationship. American Economic Review 81, 279-288.

Campello, M., C. Lin, Y. Ma, and H. Zou (2011). The Real and Financial Implications of Corporate Hedging. Journal of Finance 66, 1615-1647.

Chiang, I.-H. E., W. K. Hughen, and J. S. Sagi (2015). Estimating Oil Risk Factors Using Information from Equity and Derivatives Markets. Journal of Finance 70, 769-804.

Clerides, S., S. Lach, and J. Tybout (1998). Is Learning by exporting Important? Micro-dynamic Evidence from Colombia, Mexico, and Morocco. Quarterly Journal of Economics 113, 903-947. 
Dixit, A. K. and R. S. Pindyck (1994). Investment Under Uncertainty. Princeton University Press.

Dolde, W. (1993). The Trajectory of Corporate Financial Risk Management. Journal of Applied Corporate Finance 6, 33-41.

Fazzari, S. and B. Petersen (1993). Working Capital and Fixed Investment: New Evidence on Financing Constraints. RAND Journal of Economics 24, 328-342.

Froot, K., D. Scharfstein, and J. Stein (1993). Risk Management: Coordinating Corporate Investment and Financing Policies. Journal of Finance 48, 1629-1658.

Gilchrist, S., J. W. Sim, and E. Zakrajšek (2014). Uncertainty, Financial Frictions, and Investment Dynamics. NBER Working Paper No. 20038.

Graham, J. R. and C. R. Harvey (2001). The Theory and Practice of Corporate Finance: Evidence from the Field. Journal of Financial Economics 60, 187-243.

Graham, J. R. and C. W. Smith (1999). Tax Incentives to Hedge. Journal of Finance 54, 2241-2262.

Haushalter, D. (2000). Financing Policy, Basis Risk, and Corporate Hedging: Evidence from Oil and Gas Producers. Journal of Finance 55, 107-152.

Jin, Y. and P. Jorion (2006). Firm Value and Hedging: Evidence from U.S. Oil and Gas Producers. Journal of Finance 61, 893-919.

Kellogg, R. (2014). The Effect of Uncertainty on Investment: Evidence from Texas Oil Drilling. American Economic Review 104, 1698-1734.

Keynes, J. M. (1936). The General Theory of Employment, Interest, and Money. Macmillan and Co., Ltd.

Kraus, A. and R. H. Litzenberger (1973). A State Preference Model of Optimal Financial Leverage. Journal of Finance 28, 911-922.

Kumar, P. and R. Rabinovitch (2013). CEO Entrenchment and Corporate Hedging: Evidence from the Oil and Gas Industry. Journal of Financial and Quantitative Analysis 48, 887-917.

Kumar, P. and V. Yerramilli (2016). Optimal Financial and Operating Leverage with Real Options. Working Paper, University of Houston.

Maddala, G. S. (1983). Limited Dependent and Qualitative Variables in Econometrics. In Econometric Society Monographs No. 3. Cambridge University Press. 
McDonald, R. and D. Siegel (1986). The value of waiting to invest. Quarterly Journal of Economics 101, 707-728.

McMahon, R. (2010). OTC Trading Vital for Energy Suppliers. Oil and Gas Finance Journal \%, http://www.ogfj.com/articles/print/volume-7/issue-1/features/otc-trading_vital.html.

Meyer, G. (2012). Electronic Trading Comes to OTC Oil Swaps. Financial Times, May 22, 2012.

Myers, S. (1977). Determinants of Corporate Borrowing. Journal of Financial Economics 2, 147175.

Nance, D. R., C. W. Smith, and C. W. Smithson (1993). On the Determinants of Corporate Hedging. Journal of Finance 48, 267-284.

Nini, G., D. C. Smith, and A. Sufi (2012). Creditor Control Rights, Corporate Governance, and Firm Value. Review of Financial Studies 25, 1713-1761.

Oster, E. (2013). Unobservable Selection and Coefficient Stability: Thoery and Validation. NBER Working Paper 19054.

Pirrong, C. (2011). The Economics of Central Clearing. International Swaps and Derivatives Association (ISDA) Working paper.

Purnanandam, A. (2008). Financial Distress and Corporate Risk Management: Theory and Evidence. Journal of Financial Economics 87, 706-739.

Rampini, A., A. Sufi, and S. Viswanathan (2014). Dynamic Risk Management. Journal of Financial Economics 111, 271-296.

Rampini, A. and S. Viswanathan (2010). Collateral, Risk Management, and the Distribution of Debt Capacity. Journal of Finance 65, 2293-2322.

Singleton, K. J. (2014). Investor Flows and the 2008 Boom/Bust in Oil Prices.

Smith, C. and R. Stulz (1985). The Determinants of Firms' Hedging Policies. Journal of Financial and Quantitative Analysis 28, 391-405.

Stein, L. C. D. and E. C. Stone (2012). The Effect of Uncertainty on Investment, Hiring, and R\&D: Causal Evidence from Equity Options. Working Paper, Arizona State University.

Strebulaev, I. A. and T. Whited (2011). Dynamic Models and Structural Estimation in Corporate Finance. Foundations and Trends in Finance 6, 1-163. 
Whited, T. M. (1992). Debt, Liquidity Constraints, and Corporate Investment: Evidence from Panel Data. Journal of Finance 47, 1425-1460. 


\section{Appendix: Definitions of Variables}

\section{Firm-Level Variables:}

We indicate the corresponding COMPUSTAT Quarterly variable names in quotes within parentheses.

- Size: Natural logarithm of total assets ('atq').

- Leverage: Ratio of long-term debt ('dltt') to total assets ('atq').

- $Q$ : Ratio of the sum of the market value of equity (i.e., 'prccq' $\times$ 'cshoq') and the book value of interest-bearing debt (i.e., 'dltt'+'dlc') to the sum of book values of equity and interest-bearing debt (i.e., 'seqq'+'dltt'+'dlc').

- Cash Flow: Ratio of the sum of net income before extraordinary items ('ibq') and depreciation \& amortization ('dpq') to the net property, plant \& equipment ('ppentq').

- Cash: Ratio of cash and equivalents ('cheq') to total assets ('atq').

- Sales: Ratio of net sales ('saleq') to the net property, plant \& equipment ('ppentq').

- Dividends: A dummy variable that indicates whether the firm paid any dividends to its common shareholders.

- CAPEX: Capital expenditure during the current fiscal quarter scaled by net property, plant \& equipment at the beginning of the quarter (i.e., lagged 'ppentq'). COMPUSTAT provides the variable 'capxy' which denotes the firm's capital expenditure for the year to date. Hence, capital expenditure during the fiscal quarter equals 'capxy' for the first fiscal quarter, and 'capxy' minus lagged 'capxy' for the second, third and fourth fiscal quarters.

- Large: A dummy variable that identifies firms that are in the top quartile by Size during the given quarter.

- Rated: A dummy variable that identifies firms with a long-term credit rating from S\&P.

- Investment Grade: A dummy variable that identifies firms with an S\&P long-term credit rating of 'BBB-' or better. Investment Grade $=0$ for firms that are either unrated or whose credit rating is worse than 'BBB-'.

- Hedging Intensity: Ratio of the number of barrels of oil hedged and the number of barrels of total oil production. The measure is computed for each fiscal quarter using the data obtained from 10-Q filings of a firm.

- $\rho(T I)$ : First order auto-correlation for pre-tax earnings of a firm. The measure is computed if we have at least four data points to compute the auto-correlation. For each year, the auto-correlation is computed using an expanding window size, i.e., the number of data points increase as the firm grows older. 
$\Delta$ Net Debt: Change in net debt (i.e., total debt minus cash and equivalents) from the previous quarter scaled by lagged assets.

$\Delta$ Debt: Change in total debt from the previous quarter scaled by lagged assets.

$\Delta$ Cash: Change in cash and equivalents from the previous quarter scaled by lagged assets.

- Profit: Ratio of earnings before taxes ('piy') to total assets ('atq').

- No Separate CFO: A dummy variable that identifies firms that do not have a separate Chief Financial Officer (CFO).

\section{Oil Price and Stock Market Measures:}

- Price Uncertainty and 6-month Price Uncertainty denote the model-free risk-neutral volatility at 365-day maturity and 180-day maturity, respectively, estimated using options on crude oil futures.

- Futures Price: Price of the crude oil futures contract closest to 1-year maturity.

- Oil Return: The 3-month rate of change in Futures Price.

- SEP500 Return: 3-month return on the S\&P500 Index, adjusted for dividend payout.

- VIX: A commonly used proxy for the volatility of the S\&P500 Index, 30 days forward. 


\section{Table 1. Descriptive Statistics}

Panel A presents summary statistics for the key variables in our panel data. Panel B presents a univariate comparison of firm characteristics between small firms (Large $=0)$ and large firms (Large $=1)$. All variables are defined in the Appendix. The panel data has one observation for each firm-quarter pair, spans the period 2Q1990 to 1Q2013, and includes the 197 firms listed in Internet Appendix.

\begin{tabular}{|c|c|c|c|c|c|c|}
\hline \multicolumn{7}{|c|}{ Panel A: Summary Statistics } \\
\hline & Mean & Median & Std. Dev. & $\mathrm{p} 25$ & p75 & $\mathrm{N}$ \\
\hline \multicolumn{7}{|c|}{ Firm Characteristics (COMPUSTAT): } \\
\hline Assets (in $\$$ million) & 2073.209 & 251.132 & 6159.437 & 47.179 & 1157.682 & 6151 \\
\hline Size & 5.476 & 5.526 & 2.263 & 3.854 & 7.054 & 6151 \\
\hline Profit & 0.086 & 0.079 & 0.102 & 0.035 & 0.144 & 4825 \\
\hline Leverage & 0.286 & 0.279 & 0.211 & 0.114 & 0.421 & 6151 \\
\hline Q & 1.782 & 1.517 & 1.030 & 1.138 & 2.075 & 6023 \\
\hline Cash & 0.072 & 0.026 & 0.111 & 0.008 & 0.078 & 6142 \\
\hline Cash Flow & 0.034 & 0.041 & 0.070 & 0.020 & 0.064 & 6064 \\
\hline Sales & 0.128 & 0.102 & 0.095 & 0.072 & 0.150 & 6149 \\
\hline Dividends & 0.367 & 0.000 & 0.482 & 0.000 & 1.000 & 6074 \\
\hline Rated & 0.374 & 0.000 & 0.484 & 0.000 & 1.000 & 6151 \\
\hline Investment Grade & 0.358 & 0.000 & 0.480 & 0.000 & 1.000 & 6151 \\
\hline No Separate CFO & 0.075 & 0.000 & 0.263 & 0.000 & 0.000 & 4166 \\
\hline CEO Pay (in $\$$ '000) & 1139.438 & 558.845 & 2917.760 & 248.320 & 1138.707 & 4124 \\
\hline CFO Pay (in $\left.\${ }^{\prime} 000\right)$ & 458.374 & 330.718 & 484.586 & 161.000 & 625.840 & 3800 \\
\hline CAPEX & 0.086 & 0.062 & 0.088 & 0.034 & 0.105 & 6068 \\
\hline$\Delta$ Net Debt & 0.014 & 0.006 & 0.103 & -0.021 & 0.041 & 6000 \\
\hline \multicolumn{7}{|l|}{ Oil Production and Hedging: } \\
\hline Oil Production ('000 bbl) & 1717.775 & 280.428 & 4054.209 & 57.000 & 1482.000 & 4019 \\
\hline Oil Hedged ('000 bbl) & 546.993 & 30.000 & 1422.903 & 0.000 & 355.000 & 3583 \\
\hline Hedging Intensity & 0.296 & 0.208 & 0.318 & 0.000 & 0.533 & 3346 \\
\hline \multicolumn{7}{|l|}{ Oil Market Characteristics: } \\
\hline Futures Price & 39.352 & 24.398 & 28.594 & 18.892 & 64.115 & 6151 \\
\hline Oil Return & 0.025 & 0.012 & 0.119 & -0.035 & 0.088 & 6151 \\
\hline 6-month Price Uncertainty & 0.321 & 0.319 & 0.083 & 0.270 & 0.369 & 6151 \\
\hline Price Uncertainty & 0.274 & 0.280 & 0.074 & 0.206 & 0.326 & 6151 \\
\hline
\end{tabular}


Panel B: Firm Characteristics by Size

\begin{tabular}{|c|c|c|c|}
\hline & Large $=0$ & Large $=1$ & $p$-value of difference \\
\hline \multicolumn{4}{|l|}{ Assets (in $\$$ million) } \\
\hline Mean & 393.7 & 7106.2 & \\
\hline Median & 115.2 & 2677.5 & \\
\hline Investment Grade & 0.178 & 0.899 & 0.000 \\
\hline No Separate CFO & 0.100 & 0.002 & 0.000 \\
\hline \multicolumn{4}{|c|}{ CEO Pay (in $\left.\${ }^{\prime} 000\right)$} \\
\hline Mean & 632.2 & 2585.4 & 0.000 \\
\hline Median & 385.5 & 1622.9 & 0.000 \\
\hline \multicolumn{4}{|c|}{ CFO Pay (in $\$$ '000) } \\
\hline Mean & 329.4 & 786.2 & 0.000 \\
\hline Median & 240.4 & 634.9 & 0.000 \\
\hline CAPEX & 0.091 & 0.071 & 0.000 \\
\hline Hedging Intensity & 0.267 & 0.378 & 0.000 \\
\hline$\Delta$ Net Debt & 0.015 & 0.011 & 0.075 \\
\hline Q & 1.809 & 1.704 & 0.001 \\
\hline Profit & 0.081 & 0.101 & 0.000 \\
\hline Leverage & 0.264 & 0.349 & 0.000 \\
\hline
\end{tabular}




\section{Table 2. Correlations}

This table presents pair-wise correlations between the key variables in our panel data. Panel A lists the pairwise correlations between price uncertainty, futures price, and the macroeconomic factors. Panel B lists the pairwise correlations between firm-level outcome variables (capital expenditure, hedging, and net debt issuance), price uncertainty, and the macroeconomic factors. Variable definitions are in the Appendix. We use $*$ to denote statistical significance at the $10 \%$ level.

Panel A: Price Uncertainty and Other Market Characteristics

\begin{tabular}{lrrrr}
\hline & Price Uncertainty & Futures Price & Macro 1st P.C. & Macro 2nd P.C. \\
\hline Price Uncertainty & 1.000 & & & \\
Futures Price & $0.601^{*}$ & 1.000 & & \\
Macro 1st P.C. & $0.526^{*}$ & $0.215^{*}$ & 1.000 & \\
Macro 2nd P.C. & $0.578^{*}$ & $0.403^{*}$ & -0.000 & 1.000 \\
\hline
\end{tabular}

Panel B: Investment, Hedging, and Price Uncertainty

\begin{tabular}{lrrr}
\hline & CAPEX & Hedging Intensity & $\Delta$ Net Debt \\
\hline CAPEX & 1.000 & & \\
Hedging Intensity & $-0.064^{*}$ & 1.000 & \\
$\Delta$ Net Debt & $0.433^{*}$ & -0.006 & 1.000 \\
Price Uncertainty & $-0.067^{*}$ & $0.142^{*}$ & $-0.069^{*}$ \\
Futures Price & $0.022^{*}$ & $0.167^{*}$ & $-0.026^{*}$ \\
Macro 1st P.C. & $-0.121^{*}$ & $0.096^{*}$ & $-0.053^{*}$ \\
Macro 2nd P.C. & -0.018 & $0.050^{*}$ & -0.005 \\
Size & $-0.065^{*}$ & $0.359^{*}$ & -0.002 \\
Leverage & $-0.091^{*}$ & $0.283^{*}$ & $-0.039^{*}$ \\
Q & $0.208^{*}$ & $-0.140^{*}$ & $0.030^{*}$ \\
Rated & $-0.052^{*}$ & $0.257^{*}$ & 0.017 \\
Cash & $0.172^{*}$ & $-0.280^{*}$ & $0.054^{*}$ \\
Cash Flow & $0.063^{*}$ & -0.011 & $-0.055^{*}$ \\
Sales & $0.094^{*}$ & $-0.227^{*}$ & $-0.048^{*}$ \\
Dividends & $-0.057^{*}$ & 0.023 & 0.017 \\
\hline
\end{tabular}




\section{Table 3. Capital Investment and Price Uncertainty}

This table reports the results of panel regressions that examine the relationship between firm-level capital investment $(C A P E X)$ and Price Uncertainty. We estimate variants of the regression

$$
\mathrm{CAPEX}_{j, t}=\alpha+\beta * \text { Price Uncertainty }+\gamma X_{j, t-1}+\lambda X_{m, t}+\varepsilon_{j, t}
$$

We estimate the above regression on a panel that has one observation for each firm-fiscal quarter pair, and spans the period 4Q1994 to 1Q2013.

We estimate the regression on the entire sample in Panel A. In Panel B, we estimate the regression in columns (1), (2) and (3) of Panel A separately for small firms (Large =0) and large firms (Large =1). We employ the full set of controls in Panel B, but suppress these coefficients to conserve space.

All variables are defined in the Appendix. Standard errors (reported in parentheses) are robust to heteroskedasticity, and are clustered by quarter. We use ${ }^{* * *},{ }^{* *}$, and * to denote statistical significance at the $1 \%, 5 \%$, and $10 \%$ levels, respectively.

Panel A: Capital Investment and Price Uncertainty (All Firms)

\begin{tabular}{|c|c|c|c|c|}
\hline & \multicolumn{4}{|c|}{ Dependent Variable $=$ CAPEX } \\
\hline & (1) & $(2)$ & (3) & $(4)$ \\
\hline \multirow[t]{2}{*}{ Price Uncertainty } & $-0.103^{* * *}$ & $-0.131^{* * *}$ & $-0.089^{* *}$ & $-0.093^{* *}$ \\
\hline & $(0.025)$ & $(0.031)$ & $(0.042)$ & $(0.041)$ \\
\hline \multirow[t]{2}{*}{ Size } & 0.366 & -0.272 & -0.198 & $-4.685^{*}$ \\
\hline & $(1.012)$ & $(1.004)$ & $(1.007)$ & $(2.718)$ \\
\hline \multirow[t]{2}{*}{ Leverage } & -0.008 & -0.006 & -0.007 & $-0.039 * * *$ \\
\hline & $(0.006)$ & $(0.007)$ & $(0.007)$ & $(0.009)$ \\
\hline \multirow[t]{2}{*}{$\mathrm{Q}$} & $0.016^{* * *}$ & $0.016^{* * *}$ & $0.015^{* * *}$ & $0.017^{* * *}$ \\
\hline & $(0.001)$ & $(0.001)$ & $(0.001)$ & $(0.002)$ \\
\hline \multirow[t]{2}{*}{ Rated } & 0.003 & 0.004 & 0.004 & $0.015^{* *}$ \\
\hline & $(0.004)$ & $(0.004)$ & $(0.004)$ & $(0.006)$ \\
\hline \multirow[t]{2}{*}{ Dividends } & $-0.007 * * *$ & $-0.006^{* * *}$ & $-0.006^{* * *}$ & 0.007 \\
\hline & $(0.002)$ & $(0.002)$ & $(0.002)$ & $(0.004)$ \\
\hline \multirow[t]{2}{*}{ Cash } & $0.099 * * *$ & $0.097 * * *$ & $0.098 * * *$ & $0.207^{* * *}$ \\
\hline & $(0.017)$ & $(0.017)$ & $(0.017)$ & $(0.025)$ \\
\hline \multirow[t]{2}{*}{ Cash Flow } & $0.074^{* * *}$ & $0.072^{* * *}$ & $0.072^{* * *}$ & $0.040 *$ \\
\hline & $(0.023)$ & $(0.023)$ & $(0.022)$ & $(0.022)$ \\
\hline
\end{tabular}

Continued on next page... 
Continued from previous page...

\begin{tabular}{|c|c|c|c|c|}
\hline & (1) & (2) & (3) & (4) \\
\hline \multirow[t]{2}{*}{ Sales } & 0.009 & 0.011 & 0.008 & $0.061^{* *}$ \\
\hline & $(0.016)$ & $(0.016)$ & $(0.016)$ & $(0.024)$ \\
\hline \multirow[t]{2}{*}{ Futures Price/1000 } & & $0.142^{* *}$ & $0.119 *$ & 0.137 \\
\hline & & $(0.065)$ & $(0.064)$ & $(0.084)$ \\
\hline \multirow[t]{2}{*}{ Macro 1st P.C. } & & & $-0.005^{* * *}$ & $-0.004^{* *}$ \\
\hline & & & $(0.002)$ & $(0.001)$ \\
\hline \multirow[t]{2}{*}{ Macro 2nd P.C. } & & & 0.002 & 0.003 \\
\hline & & & $(0.005)$ & $(0.004)$ \\
\hline \multirow[t]{2}{*}{ Constant } & $0.074^{* * *}$ & $0.079^{* * *}$ & $0.069^{* * *}$ & $0.076^{* * *}$ \\
\hline & $(0.008)$ & $(0.008)$ & $(0.011)$ & $(0.014)$ \\
\hline Observations & 5799 & 5799 & 5799 & 5799 \\
\hline$R^{2}$ & 0.079 & 0.080 & 0.083 & 0.221 \\
\hline Fiscal Quarter Dummies & Yes & Yes & Yes & Yes \\
\hline Firm Fixed Effects & No & No & No & Yes \\
\hline
\end{tabular}

Panel B: Variation by Firm Size

\begin{tabular}{|c|c|c|c|c|c|c|}
\hline & \multicolumn{6}{|c|}{ Dependent Variable $=$ CAPEX } \\
\hline & $\begin{array}{c}\text { Large }=0 \\
(1)\end{array}$ & $\begin{array}{c}\text { Large }=1 \\
(2)\end{array}$ & $\begin{array}{c}\text { Large }=0 \\
(3)\end{array}$ & $\begin{array}{c}\text { Large }=1 \\
(4)\end{array}$ & $\begin{array}{c}\text { Large }=0 \\
(5)\end{array}$ & $\begin{array}{c}\text { Large }=1 \\
(6)\end{array}$ \\
\hline Price Uncertainty & $\begin{array}{r}-0.173^{* * *} \\
(0.028)\end{array}$ & $\begin{array}{r}0.017 \\
(0.031)\end{array}$ & $\begin{array}{r}-0.177^{* * * *} \\
(0.033)\end{array}$ & $\begin{array}{r}-0.012 \\
(0.033)\end{array}$ & $\begin{array}{r}-0.126^{* * *} \\
(0.045)\end{array}$ & $\begin{array}{r}0.001 \\
(0.045)\end{array}$ \\
\hline Futures Price/1000 & & & $\begin{array}{r}0.020 \\
(0.079)\end{array}$ & $\begin{array}{r}0.251^{* * * *} \\
(0.061)\end{array}$ & $\begin{array}{r}-0.004 \\
(0.076)\end{array}$ & $\begin{array}{r}0.234^{* * *} \\
(0.063)\end{array}$ \\
\hline Macro 1st P.C. & & & & & $\begin{array}{r}-0.006^{* * *} \\
(0.002)\end{array}$ & $\begin{array}{r}-0.002 \\
(0.002)\end{array}$ \\
\hline Macro 2nd P.C. & & & & & $\begin{array}{r}0.002 \\
(0.005)\end{array}$ & $\begin{array}{r}0.002 \\
(0.004)\end{array}$ \\
\hline$\chi^{2}$ (difference) & 48.71 & - & 28.62 & - & 11.59 & - \\
\hline$p$-value (difference) & 0.000 & - & 0.000 & - & 0.001 & - \\
\hline Observations & 4308 & 1491 & 4308 & 1491 & 4308 & 1491 \\
\hline$R^{2}$ & 0.085 & 0.098 & 0.085 & 0.105 & 0.089 & 0.107 \\
\hline All controls & Yes & Yes & Yes & Yes & Yes & Yes \\
\hline
\end{tabular}




\section{Table 4. Hedging Intensity and Price Uncertainty}

This table reports the results of panel regressions that examine the relationship between Hedging Intensity and Price Uncertainty. We estimate the regression

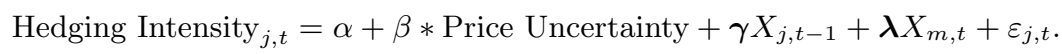

We estimate this regression on a panel that has one observation for each firm-fiscal quarter pair, spans the period 1Q1995 to 1Q2013, and includes the 126 firms for which we are able to obtain information on hedging intensity from their SEC filings.

We estimate the regression on the entire sample in Panel A. In Panel B, we estimate the regression in columns (1), (2) and (3) of Panel A separately for small firms (Large =0) and large firms (Large =1). We employ the full set of controls in Panel B, but suppress these coefficients to conserve space.

All variables are defined in the Appendix. Standard errors (reported in parentheses) are robust to heteroskedasticity, and are clustered by quarter. We use ${ }^{* * *},{ }^{* *}$, and $*$ to denote statistical significance at the $1 \%, 5 \%$, and $10 \%$ levels, respectively.

Panel A: Hedging Intensity and Price Uncertainty (All Firms)

\begin{tabular}{|c|c|c|c|c|}
\hline & \multicolumn{4}{|c|}{ Dependent Variable $=$ Hedging Intensity } \\
\hline & (1) & $(2)$ & (3) & $(4)$ \\
\hline \multirow[t]{2}{*}{ Price Uncertainty } & $0.391^{* * *}$ & $0.226^{*}$ & $0.430 * *$ & 0.021 \\
\hline & $(0.131)$ & $(0.128)$ & $(0.169)$ & $(0.163)$ \\
\hline \multirow[t]{2}{*}{ Size } & $53.487^{* * *}$ & $48.644^{* * *}$ & $49.060^{* * *}$ & $60.920 * * *$ \\
\hline & $(3.277)$ & $(3.017)$ & $(3.052)$ & $(7.962)$ \\
\hline \multirow[t]{2}{*}{ Leverage } & $0.292^{* * *}$ & $0.304^{* * *}$ & $0.303^{* * *}$ & $0.121^{* * *}$ \\
\hline & $(0.035)$ & $(0.034)$ & $(0.034)$ & $(0.030)$ \\
\hline \multirow[t]{2}{*}{ Q } & $-0.014^{* * *}$ & $-0.019^{* * *}$ & $-0.020^{* * *}$ & 0.000 \\
\hline & $(0.004)$ & $(0.004)$ & $(0.004)$ & $(0.004)$ \\
\hline \multirow[t]{2}{*}{ Rated } & $-0.068^{* * *}$ & $-0.065^{* * *}$ & $-0.065^{* * *}$ & $-0.054^{* * *}$ \\
\hline & $(0.009)$ & $(0.010)$ & $(0.010)$ & $(0.018)$ \\
\hline \multirow[t]{2}{*}{ Dividends } & $-0.061^{* * *}$ & $-0.055^{* * *}$ & $-0.056^{* * *}$ & 0.004 \\
\hline & $(0.009)$ & $(0.009)$ & $(0.009)$ & $(0.013)$ \\
\hline \multirow[t]{2}{*}{ Cash } & $-0.226^{* * *}$ & $-0.242^{* * *}$ & $-0.246^{* * *}$ & $-0.139 * *$ \\
\hline & $(0.040)$ & $(0.040)$ & $(0.040)$ & $(0.062)$ \\
\hline \multirow[t]{2}{*}{ Cash Flow } & $0.207^{* *}$ & $0.200^{* *}$ & $0.163^{* *}$ & 0.070 \\
\hline & $(0.083)$ & $(0.076)$ & $(0.072)$ & $(0.074)$ \\
\hline
\end{tabular}

Continued on next page... 
Continued from previous page...

\begin{tabular}{|c|c|c|c|c|}
\hline & (1) & $(2)$ & $(3)$ & (4) \\
\hline Sales & $\begin{array}{r}-0.392^{* * *} \\
(0.069)\end{array}$ & $\begin{array}{r}-0.372^{* * *} \\
(0.068)\end{array}$ & $\begin{array}{r}-0.366^{* * *} \\
(0.068)\end{array}$ & $\begin{array}{r}0.086 \\
(0.114)\end{array}$ \\
\hline Futures Price/1000 & & $\begin{array}{r}0.801 * * * \\
(0.205)\end{array}$ & $\begin{array}{r}0.813^{* * *} \\
(0.223)\end{array}$ & $\begin{array}{r}0.807 * * * \\
(0.284)\end{array}$ \\
\hline Macro 1st P.C. & & & $\begin{array}{r}-0.003 \\
(0.007)\end{array}$ & $\begin{array}{r}0.007 \\
(0.006)\end{array}$ \\
\hline Macro 2nd P.C. & & & $\begin{array}{r}-0.053^{* * *} \\
(0.016)\end{array}$ & $\begin{array}{c}-0.023^{*} \\
(0.013)\end{array}$ \\
\hline Constant & $\begin{array}{r}-0.090^{* *} \\
(0.040)\end{array}$ & $\begin{array}{r}-0.051 \\
(0.037)\end{array}$ & $\begin{array}{r}-0.107^{* *} \\
(0.045)\end{array}$ & $\begin{array}{r}-0.128^{* *} \\
(0.049)\end{array}$ \\
\hline Observations & 3259 & 3259 & 3259 & 3259 \\
\hline$R^{2}$ & 0.211 & 0.214 & 0.217 & 0.584 \\
\hline Firm Fixed Effects & No & No & No & Yes \\
\hline
\end{tabular}

Panel B: Variation by Firm Size

\begin{tabular}{|c|c|c|c|c|c|c|}
\hline & \multicolumn{6}{|c|}{ Dependent Variable $=$ Hedging Intensity } \\
\hline & $\begin{array}{c}\text { Large }=0 \\
(1)\end{array}$ & $\begin{array}{c}\text { Large }=1 \\
(2)\end{array}$ & $\begin{array}{c}\text { Large }=0 \\
(3)\end{array}$ & $\begin{array}{c}\text { Large }=1 \\
(4)\end{array}$ & $\begin{array}{c}\text { Large }=0 \\
(5)\end{array}$ & $\begin{array}{c}\text { Large }=1 \\
(6)\end{array}$ \\
\hline Price Uncertainty & $\begin{array}{r}0.031 \\
(0.122)\end{array}$ & $\begin{array}{r}1.028^{* * *} \\
(0.206)\end{array}$ & $\begin{array}{r}0.030 \\
(0.129)\end{array}$ & $\begin{array}{r}0.665^{* * *} \\
(0.181)\end{array}$ & $\begin{array}{r}0.256 \\
(0.164)\end{array}$ & $\begin{array}{r}0.580^{* *} \\
(0.256)\end{array}$ \\
\hline Futures Price/1000 & & & $\begin{array}{r}0.006 \\
(0.185)\end{array}$ & $\begin{array}{r}3.915^{* * *} \\
(0.625)\end{array}$ & $\begin{array}{r}0.011 \\
(0.201)\end{array}$ & $\begin{array}{r}4.116^{* * *} \\
(0.642)\end{array}$ \\
\hline Macro 1st P.C. & & & & & $\begin{array}{c}-0.004 \\
(0.007)\end{array}$ & $\begin{array}{r}0.015 \\
(0.009)\end{array}$ \\
\hline Macro 2nd P.C. & & & & & $\begin{array}{r}-0.056^{* * *} \\
(0.018) \\
\end{array}$ & $\begin{array}{r}-0.024 \\
(0.027) \\
\end{array}$ \\
\hline$\chi^{2}$ (difference) & 31.42 & - & 13.89 & - & 2.74 & - \\
\hline$p$-value (difference) & 0.000 & - & 0.000 & - & 0.098 & - \\
\hline Observations & 2408 & 851 & 2408 & 851 & 2408 & 851 \\
\hline$R^{2}$ & 0.212 & 0.216 & 0.212 & 0.273 & 0.215 & 0.277 \\
\hline All controls & Yes & Yes & Yes & Yes & Yes & Yes \\
\hline
\end{tabular}




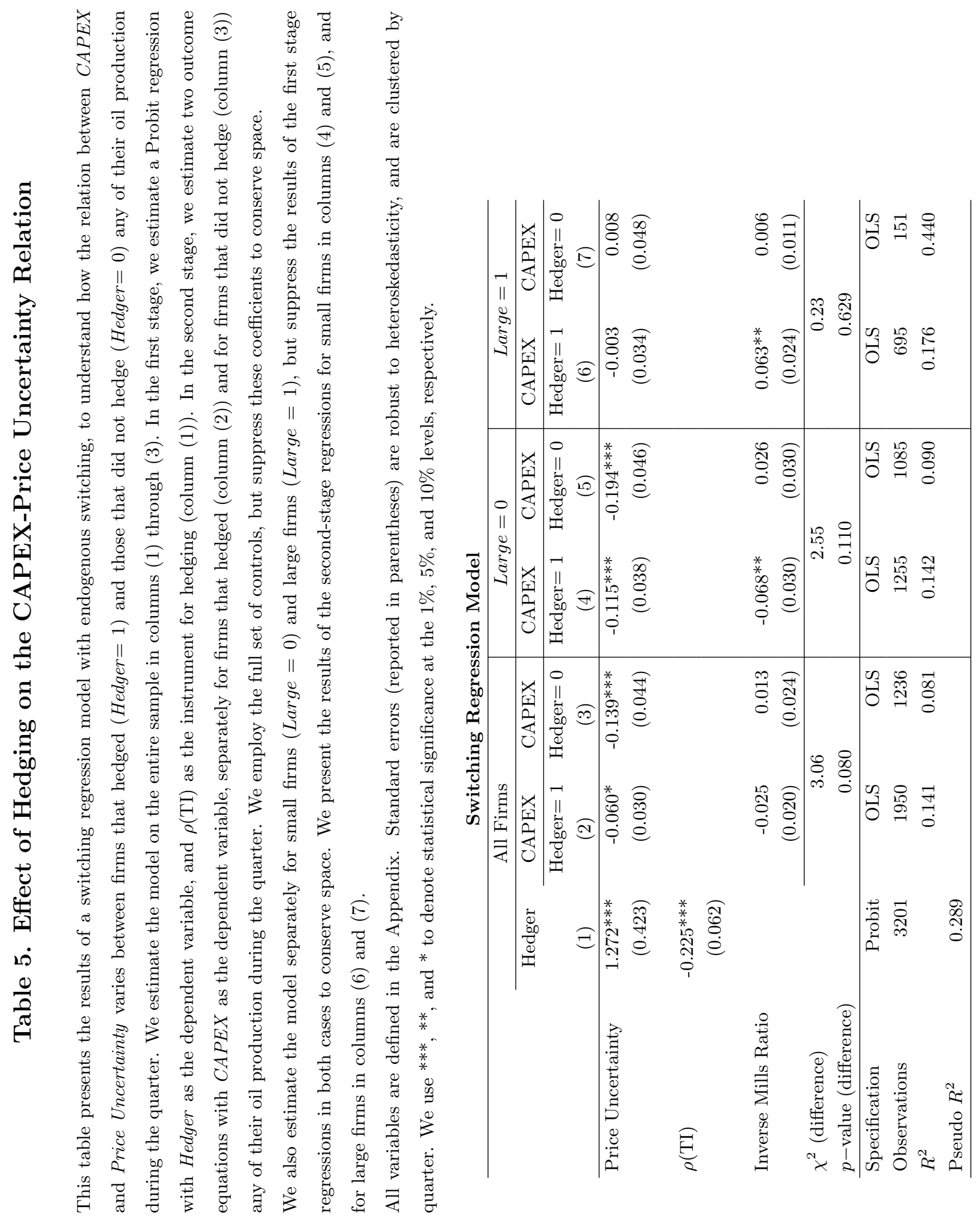




\section{Table 6. Net Debt Issuance and Price Uncertainty}

This table reports the results of panel regressions that examine the relationship between firm-level net debt issuance and oil Price Uncertainty. We estimate variants of the regression

$$
Y_{j, t}=\alpha+\beta * \text { Price Uncertainty }+\gamma X_{j, t-1}+\lambda X_{m, t}+\varepsilon_{j, t}
$$

We estimate this regression on a panel that has one observation for each firm-fiscal quarter pair, and spans the period 4Q1994 to 1Q2013. In Panel A, we estimate the regression on the entire sample. The dependent variable is $\Delta N e t$ Debt in columns (1), (2) and (3), DDebt in column (4), and $\Delta$ Cash in column (5).

In Panel B, we estimate the regression in columns (1), (2) and (3) of Panel A separately for small firms (Large =0) and large firms (Large $=1$ ). We employ the full set of controls in Panel B, but suppress these coefficients to conserve space.

In Panel C, we estimate a switching regression model with endogenous switching using $\Delta$ Net Debt as the dependent variable. We first estimate the model on the entire sample, where we report the results of the first-stage Probit regression with Hedger as the dependent variable in column (1), and the results of the two outcome equations with $\Delta$ Net Debt as the dependent variable for firms that hedged (column (2)) and for firms that did not hedge (column (3)). Next, we estimate this model separately for small firms (Large $=0$ ) and large firms (Large $=1)$, but suppress the results of the first stage regressions in both cases to conserve space. We present the results of the second-stage regressions for small firms in columns (4) and (5), and for large firms in columns (6) and (7).

All variables are defined in the Appendix. Standard errors (reported in parentheses) are robust to heteroskedasticity, and are clustered by quarter. We use ${ }^{* * *},{ }^{* *}$, and $*$ to denote statistical significance at the $1 \%, 5 \%$, and $10 \%$ levels, respectively. 
Panel A: Net Debt Issuance and Price Uncertainty (All Firms)

\begin{tabular}{|c|c|c|c|c|c|}
\hline & $\Delta$ Net Debt & $\Delta$ Net Debt & $\Delta$ Net Debt & $\Delta$ Debt & $\Delta$ Cash \\
\hline & $(1)$ & $(2)$ & $(3)$ & $(4)$ & $(5)$ \\
\hline \multirow[t]{2}{*}{ Price Uncertainty } & $-0.096^{* * *}$ & $-0.134^{* * *}$ & $-0.133^{* * *}$ & $-0.077^{* * *}$ & 0.015 \\
\hline & $(0.026)$ & $(0.041)$ & $(0.047)$ & $(0.018)$ & $(0.012)$ \\
\hline \multirow[t]{2}{*}{ Industry CAPEX } & $0.466^{* * *}$ & $0.615^{* * *}$ & $0.510^{* * *}$ & $0.430^{* * *}$ & -0.027 \\
\hline & $(0.109)$ & $(0.135)$ & $(0.147)$ & $(0.086)$ & $(0.047)$ \\
\hline \multirow[t]{2}{*}{ Size } & -0.679 & -0.346 & $-5.843^{* *}$ & $-2.702^{* * *}$ & $-1.811^{* * *}$ \\
\hline & $(1.027)$ & $(0.957)$ & $(2.673)$ & $(0.804)$ & $(0.411)$ \\
\hline \multirow[t]{2}{*}{ Rated } & $0.006^{*}$ & 0.006 & 0.006 & $0.010^{* * *}$ & $0.004^{* * *}$ \\
\hline & $(0.004)$ & $(0.004)$ & $(0.007)$ & $(0.004)$ & $(0.001)$ \\
\hline \multirow[t]{2}{*}{ Tangibility } & -0.001 & -0.002 & $-0.063^{* * *}$ & $0.029 * * *$ & $0.024^{* * *}$ \\
\hline & $(0.010)$ & $(0.010)$ & $(0.016)$ & $(0.007)$ & $(0.006)$ \\
\hline \multirow[t]{2}{*}{ Profitability } & -0.026 & -0.027 & 0.006 & -0.014 & $0.017^{* *}$ \\
\hline & $(0.018)$ & $(0.018)$ & $(0.019)$ & $(0.015)$ & $(0.007)$ \\
\hline \multirow[t]{2}{*}{ Q } & 0.002 & 0.002 & 0.003 & $0.002^{* *}$ & 0.001 \\
\hline & $(0.001)$ & $(0.001)$ & $(0.002)$ & $(0.001)$ & $(0.001)$ \\
\hline \multirow[t]{2}{*}{ Futures Price/1000 } & & $-0.147^{*}$ & -0.036 & & \\
\hline & & $(0.082)$ & $(0.105)$ & & \\
\hline \multirow[t]{2}{*}{ Macro 1st P.C. } & & 0.003 & $0.004^{*}$ & & \\
\hline & & $(0.002)$ & $(0.002)$ & & \\
\hline \multirow[t]{2}{*}{ Macro 2nd P.C. } & & $0.016^{* * *}$ & $0.018^{* * *}$ & & \\
\hline & & $(0.004)$ & $(0.004)$ & & \\
\hline \multirow[t]{2}{*}{ Constant } & 0.011 & 0.017 & $0.094^{* * *}$ & -0.005 & $-0.013^{* *}$ \\
\hline & $(0.012)$ & $(0.015)$ & $(0.018)$ & $(0.008)$ & $(0.006)$ \\
\hline Observations & 5842 & 5842 & 5842 & 5842 & 5977 \\
\hline$R^{2}$ & 0.012 & 0.014 & 0.057 & 0.017 & 0.012 \\
\hline Firm Fixed Effects & No & No & Yes & No & $\mathrm{No}$ \\
\hline
\end{tabular}


Panel B: Variation by Firm Size

\begin{tabular}{|c|c|c|c|c|c|c|}
\hline & \multicolumn{6}{|c|}{ Dependent Variable $=\Delta$ Net Debt } \\
\hline & $\begin{array}{c}\text { Large }=0 \\
(1)\end{array}$ & $\begin{array}{c}\text { Large }=1 \\
(2)\end{array}$ & $\begin{array}{c}\text { Large }=0 \\
(3)\end{array}$ & $\begin{array}{c}\text { Large }=1 \\
(4)\end{array}$ & $\begin{array}{c}\text { Large }=0 \\
(5)\end{array}$ & $\begin{array}{c}\text { Large }=1 \\
(6)\end{array}$ \\
\hline Price Uncertainty & $\begin{array}{r}-0.146^{* * *} \\
(0.031)\end{array}$ & $\begin{array}{r}0.017 \\
(0.035)\end{array}$ & $\begin{array}{r}-0.105^{* * *} \\
(0.038)\end{array}$ & $\begin{array}{r}0.023 \\
(0.044)\end{array}$ & $\begin{array}{r}-0.190^{* * *} \\
(0.044)\end{array}$ & $\begin{array}{r}0.015 \\
(0.056)\end{array}$ \\
\hline Industry CAPEX & $\begin{array}{r}0.429^{* * *} \\
(0.128)\end{array}$ & $\begin{array}{r}0.444^{* * *} \\
(0.135)\end{array}$ & $\begin{array}{r}0.551^{* * *} \\
(0.160)\end{array}$ & $\begin{array}{c}0.467^{* *} \\
(0.180)\end{array}$ & $\begin{array}{r}0.635^{* * *} \\
(0.144)\end{array}$ & $\begin{array}{r}0.510^{* *} \\
(0.195)\end{array}$ \\
\hline Futures Price/1000 & & & $\begin{array}{r}-0.201^{* *} \\
(0.095)\end{array}$ & $\begin{array}{r}-0.037 \\
(0.133)\end{array}$ & $\begin{array}{r}-0.229^{* * *} \\
(0.086)\end{array}$ & $\begin{array}{r}-0.043 \\
(0.133)\end{array}$ \\
\hline Macro 1st P.C. & & & & & $\begin{array}{c}0.004^{*} \\
(0.002)\end{array}$ & $\begin{array}{r}0.001 \\
(0.002)\end{array}$ \\
\hline Macro 2nd P.C. & & & & & $\begin{array}{r}0.021^{* * *} \\
(0.004)\end{array}$ & $\begin{array}{r}-0.000 \\
(0.006)\end{array}$ \\
\hline$\chi^{2}$ (difference) & 20.29 & - & 8.63 & - & 17.25 & - \\
\hline$p$-value (difference) & 0.000 & - & 0.003 & - & 0.000 & - \\
\hline Observations & 4349 & 1493 & 4349 & 1493 & 4349 & 1493 \\
\hline$R^{2}$ & 0.016 & 0.013 & 0.018 & 0.013 & 0.020 & 0.013 \\
\hline All controls & Yes & Yes & Yes & Yes & Yes & Yes \\
\hline
\end{tabular}




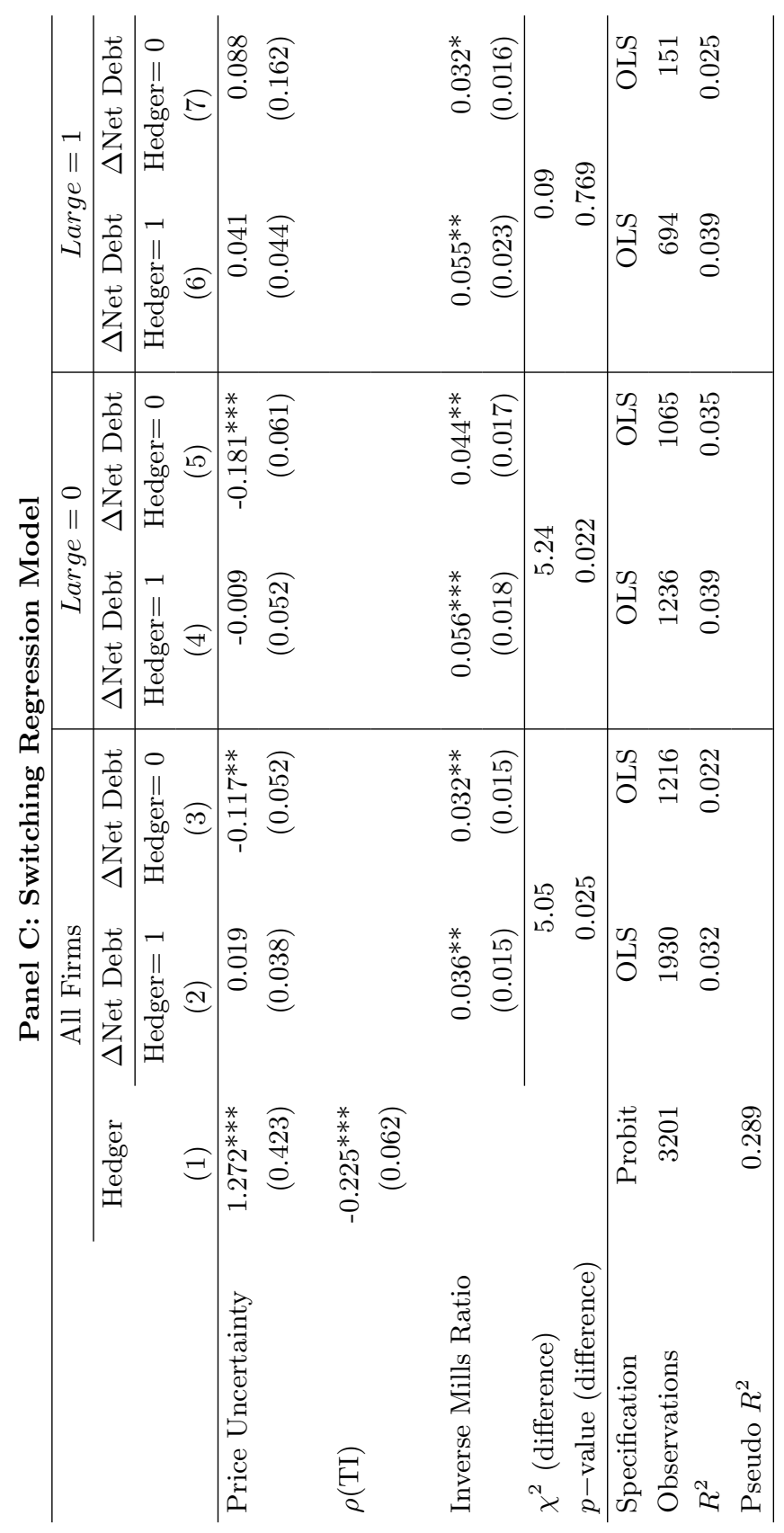

